\title{
Building Capacity for Sustainability: Strategic Planning Processes for Local Sustainable Development Practices in Western Balkan
}

\author{
SlobodAn MilutinOVic \& ANA JOLOVIC
}

\begin{abstract}
Municipalities on the Western Balkan have made significant progress in their strategic approach to local development after 2000. A number of municipalities have already developed and implemented strategic plans for local sustainable development. However, differences in capacities, management skills and motivation among local governments are easy to observe. The lack of substantial decentralization efforts, low internal capacity in municipalities, overlapping jurisdictions between central and local levels, a culture of non-participation and an unfavourable economic environment jeopardize the success of local development efforts. This paper analyzes local sustainable development planning processes and practices in three Western Balkan countries (Serbia, Montenegro and Bosnia - Herzegovina) by using the Drina River Basin as a case study.

KEYWORDs: • sustainable development $\bullet$ local community $\bullet$ Western Balkan $\bullet$ Serbia $\bullet$ Montenegro $\bullet$ Bosnia -Herzegovina
\end{abstract}

CORRESPONDENCE AdDRESS: Slobodan Milutinovic, Ph. D., University of Niš, Faculty of Occupational Safety, Carnojevica 10a, 18000 Niš, Serbia, email: boban40@yahoo.com. Ana Jolovic, Ph. D., ISM University of Management and Economics, Faculty of Economics and Political Science, Arklių St. 18, Vilnius 001305, Lithuania, email: anajolovic@yahoo.com. 
Over the decade or so, the concept of sustainable development has become a shibboleth. It is widely accepted as the way to live in harmony with the environment. Achieving sustainability of national development requires a longterm strategic approach that either integrates or encompasses different development processes in such a way that they can be as sophisticated as the development challenges are complex. In accordance with the conclusions of the Johannesburg Conference, local governments implementing sustainable development are bound to enter a decade of accelerated action towards the creation of sustainable communities and protection of common world goods.

In this paper, we are interested in exploring current efforts, capacities, and prospects for local sustainability in the Western Balkan countries, particularly Serbia, Montenegro and Bosnia - Herzegovina. The study aims to help improve understanding of interactions between local government institutions, central governments and civil society in Drina River Basin municipalities in achieving local sustainable development, as well as the conditions enabling improved communication networks and capacity building. When assessing the current situation of local sustainable development processes and practices in the selected region, particular attention is given to sustainable development frameworks and activities at national and local levels, local environmental institutions, capacities, capabilities and competences of local administrations, responsibilities, communication, factors and conditions allowing organisational capacity development to address sustainable development requirements at the local government level, and the impact of participatory measures at the level of involvement of different stakeholders in decision making processes.

\section{Theoretical Considerations}

Despite the near-universal recognition that sustainable communities are a desirable policy goal, there is less certainty about what this might mean in practice. Many scholars have argued that translation of sustainable development goals into concrete action proves to be a much more difficult challenge (Lafferty 2004; Lafferty and Meadowcraft 2000), particularly at the local level, in developing countries, and in the countries with a low level of decentralisation.

Local planning and development decisions have a significant impact on global sustainability. As emphasized by Rees (1988), sustainable development planning is a social planning process, not singularly aimed at the reduction of risk and impact, but at positioning a local administration towards different and conflicting aims and values in order to achieve long-term objectives. The decentralizing power of local administrative organisations is distributing power in decisionmaking regarding various tasks for local administrative organizations and local 
people. Although local governments are not necessarily the only agencies charged with community planning and development, they are the only locally elected, representative and accountable bodies responsible for community decisionmaking. Strategic planning for sustainable development has frequently been introduced as a tool to initiate change by continuous adaptation and learning rather than by challenging the existing institutions and power structures (Volkery at al. 2006:2048). However, throughout the world, local governments still struggle with the challenge of linking stakeholder-based strategic planning with the local government's statutory planning requirements (Brugmann 1996; Milutinovic 2003).

As Bulkeley and Betsill concluded after the discussion of a UK case "in seeking to explain the apparent gap between the growing rhetoric of the importance of sustainable cities on the one hand and the reality of urban development, planning and transport on the other, many have turned to the processes that take place within urban arenas (such as competencies of policy makers, inter-departmental tensions within the local authority, problems of changing the existing institutionalised practices, and the strength of entrenched policy coalitions) and hold the key to redressing sustainability at the local level" (Bilkeley and Betsill 2005:57). Moreover, they suggest that it is necessary to engage in the processes that shape local capability and political will for sustainable development at both local and central levels of government.

Partly as a result of international development and decentralisation processes, the sustainable communities agenda has also gained significant ground in the Western Balkans countries over the past decade (Milutinovic at al. 2005; Milutinovic 2007; Munitlak - Ivanovic at al. 2009; Golusin and Munitlak - Ivanovic 2009). In the Western Balkan, many local authorities have adopted local sustainable development strategies (LSDS). They see them as a means through which to reclaim some of the policy ground lost during the period of political turbulence and wars of the 1990s. For example, more than 30 out of 167 municipalities have adopted local SD strategies in Serbia so far, and they have initiated the implementation of local Agenda 21 (LA21) (Milutinovic 2009). When discussing local sustainable development planning in the Western Balkans, one of the key issues is the role of donors. Most local strategies are driven by international donor programmes aimed at building up the capacity of local actors to deal with the issues of local sustainability. VanDeveer and Sagar define "capacity" as consisting of three overlapping categories: a capacity to recognise, analyse and help define environmental problems and their causes; a capacity to jointly decide on appropriate management processes, and an implementation capacity (VanDeveer and Sagar 2005:265). When conceptualising donor assistance to local sustainable development initiatives, the Organisation for Economic Cooperation and Development (OECD) urges the donors to take a bottom-up approach aimed at (1) recognising, analysing and helping to define environmental problems and their 
causes; (2) encouraging joint decision making and management processes (i.e., not imposed by donors), and (3) locating local initiatives in the context of global implementation capacity (OECD 1995). This has not always been the case in the Western Balkans.

However, as in many other regions, the local sustainable development planning processes in the Western Balkans have not brought any substantial changes in local sustainability as expected. This paper aims to explore some of the reasons for the lack of results by analysing the municipalities from the cross-border Drina River Basin region (geographical area delineated by the Drina River and shared among Bosnia - Herzegovina, Montenegro, and Serbia), particularly their strategic planning processes for local sustainable development, and practices (SPPLSDP).

\section{$3 \quad$ Background to the Study}

The Drina River Basin encircles the central part of the Dinaric Mountains and covers 19,946 sq $\mathrm{km}$ of a mostly mountainous terrain situated in Bosnia Herzegovina, Montenegro, and Serbia. This area is home to 650,000 people. The Drina River catchment area has a relatively low average population density, rich biodiversity, and high quality water resources. The Drina River Basin has around 60 relatively undeveloped and mainly rural municipalities. In 2004, the municipalities in this Basin established the Drina River Committee (with support from the Norwegian Ministry of Foreign Affairs) as the main cross-border body for coordinating development of this area. Approximately 20 municipalities from the Basin participate in this Committee and it is endorsed by the governments of Bosnia - Herzegovina, Montenegro, and Serbia.

This research is based on the following information:

- the analysis of existing country-based strategic documents and processes, as well as local strategic documents and implementation processes in 25 randomly selected municipalities in the Drina River Basin (see Figure 1 for the list of municipalities);

- interviews conducted with representatives of the central and local governments and civil sector during August and September 2009.

\section{$4 \quad$ Contextual Analysis}

\section{Political context}

The South-Eastern European (SEE) region, sometimes also referred to as the Western Balkan, is highly diverse in terms of its geography, ecosystems, ethnic groups, religions, culture, and economies, but it also shares a common turbulent history. The diversity of this part of Europe was severely abused during a series of conflicts and instability between 1991 and 2001 following the dissolution of 
Yugoslavia and the collapse of a socialist political system. Since then, reconstruction and rehabilitation have been the main common characteristics of the region. Due to the complexity of this process, the region today still represents a geographical gap in the enlarged European Union, but it has a clear European perspective that includes valuing a high-quality environment, and sustainable development (for example, according to the Global Footprint Network data, the national ecological footprints are fewer than 1 in all the three countries studied: the Republic of Serbia, the Republic of Montenegro, and the Republic of Bosnia Herzegovina). The EU perspective is currently the main political driver for changes in the region, structured around the Stabilisation and Association Process and Accession Process for all the three subject countries.

The European Union (EU) accession facilitation in the field of environment has also become the overall purpose of the Regional Environmental Reconstruction Programme agreed by the countries of the region and by the EU Commission in 2000, and reviewed in 2003. The Joint Statement released in Skopje in 2003 presents a wide scope of environmental policy reform underway in the SEE ranging from transposition and implementation of individual items of EU legislation to integration of environmental objectives into sectoral (issue-based) policies. The Joint Statement of the Regional Ministerial Conference "Environmental Policies in the Context of European Integration" in Montenegro in 2006, involving representatives of Ministries of Environment, Agriculture and Tourism, provides the framework for sectoral integration. The Energy Community Treaty, signed in Athens on 25 October 2005, provides the framework for energyrelated environmental and sustainability issues, and the UNECE Strategy on Education for Sustainable Development, adopted in Vilnius in 2005, provides a context for adapting educational systems to the needs of sustainable development. Moreover, the SEE countries (including the three analysed ones) signed a common joint statement on education for sustainable development (ESD) during the Belgrade Conference "Environment for Europe" on 10 October 2007. The SEE countries believe that it is essential to show a common expression of efforts, aspirations and needs towards Education for Sustainable Development in the region. The joint statement appreciated the Vilnius Strategy and aimed to address the appropriate policies to embed ESD within the national regulatory and operational frameworks as well as regional initiatives. It declares that while many new policies have been developed, there are problems with ensuring a coordinated approach to ESD across government bodies, and that there are limited knowledge, institutional support, and human and financial resources in the region to ensure the integration of ESD into the education system.

\section{Decentralisation Level and the Position of Local Self-Governments}

Significant efforts have been made in recent years to strengthen local selfgovernment in Serbia, Bosnia - Herzegovina, and Montenegro. Despite that, the 
problems of weak local government institutions could be described in more detail as follows:

- The (as yet) centralised regulatory framework. Despite the changes in regulatory frameworks and the fact that all the three countries have signed the European Charter of Local Self-Government, the degree of autonomy the municipalities have today is clearly insufficient for them to take a proactive role in meeting the overwhelming challenges caused by the social and economic collapse that affected the whole region. One of the most important points, i.e., the funding of municipalities from a central government does not provide municipalities with sufficient means to adequately undertake infrastructural investments and social programmes, or to create an environment for economic development.

- Inability to provide an appropriate economic environment. Existing practices do not allow private enterprises to flourish due to lengthy and sometimes deliberately obstructive and bureaucratic procedures, heavy taxes on businesses, poor investment in infrastructure, and a general lack of transparency and accountability. Any serious start-up business or investor must overcome these obstacles and risks that encourage an environment for corruption.

- Lack of management skills. The majority of the municipalities are overstaffed with employees who do not always have the education or motivation to benefit from training programmes.

- Lack of civil participation. The concept of an active civil society is not widely understood. Consequently, there is distrust both in centrally and locally elected institutions because the decisions taken by local and municipal government departments rarely correspond to the perceived needs of local communities. The pervasive distrust in politically manipulated municipal councils reflects the frustrations of powerless communities to rectify the serious flaws in the delivery of services. Although the culture of authoritarian management styles is the general inheritance from the past government structures, authoritarian decisionmaking is more pronounced in some municipalities and communities than in others.

\section{Sustainable development Frameworks and Activities at the National and Local Levels}

The government of Serbia adopted the National Sustainable Development Strategy (NSDS) in May 2008. Moreover, the government of Serbia recently developed the Action Plan for NSDS implementation (March 2009) and initiated the implementation process. The NSDS process in Serbia was led by the National Council for Sustainable Development, established in 2003. The entire NSDS development in Serbia was organised as a participatory process. The Serbian 
NSDS and Action Plan pay significant attention to social issues; local issues are considered important in NSDS as well (Milutinovic \& Radojevic 2009).

In Bosnia - Herzegovina, neither the Republic of Srpska nor the Federation of Bosnia - Herzegovina have drawn up their national sustainable development strategies up to now, while the cantons develop their long-term development plans or strategies in the Federation. Some of the cantons (Sarajevo, Tuzla) have also incorporated some elements of sustainable development into their development strategies. Yet any efforts to ensure that environmental considerations are incorporated within policy and planning decisions in Bosnia - Herzegovina are frustrated by the fact that decision-making for various policy areas takes place through various tiers of government. Lack of clarity and openness regarding where responsibility lies for decision-making is still in place (Fagan 2008).

In April 2007, the Government of Montenegro adopted the National Strategy for Sustainable Development along with the Action Plan for the period from 2007 to 2012. The Strategy and the Action Plan cover three pillars of sustainable development: economic, social, and environmental. The NSSD rests upon the economic development, social, environmental, ethical, and cultural visions for sustainable development of Montenegro. The time horizon for NSSD is from 2006 to 2011 with the first Action Plan developed for the 2006-2009 period. However, local sustainable development was not considered as a priority.

In Serbia, the NSDS implementation was planned through different institutions because the strategy is cross-sectoral. Therefore, according to NSDS, the Office for Sustainable Development had to be officially established as a coordinator for strategy implementation and monitoring.

Montenegro developed a similar structure for NSDS strategy. In 2002, the National Council for Sustainable Development was established as an advisory body for the Government regarding the sustainable development issues. The Prime Minister chairs the National Council composed of the representatives of different societal stakeholders. In 2006, the NCSD composition was expanded in order to include a wider range of actors and interest groups.

\section{Implementation Capacity}

The analysis of the NSDS implementation capacity at the national and local levels indicates a high level of heterogeneity in both countries. At the central level, one can identify the key stakeholders (the Sustainable Development Unit in Serbia and the Office for Sustainable Development in Montenegro) and different institutions as the main participants in the Strategy implementation. Depending on the institution, the human and technical capacities are at different levels. The proof can be found in the Serbian coordinators network established by the Sustainable 
Development Unit. In order to enhance coordination and manage Strategy implementation, a coordinator per institution is appointed, although in some cases, a coordinator team is appointed, depending on the institution size and role in the implementation process. Looking at this year's action plan results and at the action plans that were prepared by various institutions and sent to the Sustainable Development Unit, one can conclude that there is a substantial variety both in quality action plans and in the approach to sustainable development, as well as their opinion of the importance of strategic planning because some institutions have provided no plans at all.

It is important to note that, on average, human and technical resources are more developed at the central than at the local level, but in both cases, the level of motivation could be analysed on a case-by-case basis.

At the local level, this heterogeneity is even more present. Depending on their size and development level, some municipalities, e.g., Valjevo, have strong human and technical capabilities as compared to those with exceptionally weak ones, e.g., Sjenica in Serbia, or Andrijevica in Montenegro. It is also noticeable that there is a correlation between municipality capacity and the capacity of the NGO sector and public participation. In weak municipalities where significant efforts should be made in capacity building, the NGOs and civil sector are almost non-existent there.

At the local level, the differences in capacities, management, and motivation are easier to observe. When analysing strategic planning, strategic documents, and implementation over the last eight years, one can conclude that the gap between strong and weak municipalities is increasing. While the strong ones are improving at least in the areas of planning and documentation, the weak ones are still at the starting point without even the internal capacity for planning.

Either strong implementation capacities at the local level do not exist or the human resources necessary for implementation are scattered throughout organisations, and the implementation of strategic documents is not the main responsibility. We did not observe any instance in which a department/sector/team was clearly identified as an implementation unit. In some cases, local selfgovernments have offices for local development, but they are usually newly established with no real influence on local budgeting and/or strategy implementation.

\section{Local Sustainable Development Planning}

Strategic planning for sustainable development (SD) at the local level in the region was developing independently of national SD initiatives. It was initiated and led 
by donor initiatives and municipal support programmes, and strengthened by the support of national associations of local self-governments. Activities include:

- Adoption of the Local Sustainable Development Strategy (LSDS) for Serbia and the Declaration on Local Sustainable Development at the National Conference on Local Sustainable Development in Belgrade in May 2005. It was the result of a joint project of the Serbian Association of Towns and Municipalities (SCTM) and the Norwegian Association of Local and Regional Authorities.

- A number of municipalities in Serbia initiated their own LA21 strategic planning processes. Most of them were project-oriented and funded by donor programmes. Currently, the EC-funded EXCHANGE II Programme helps develop municipal SD strategies in 20 municipalities across Serbia. By the end of 2008 , some $30 \%$ of municipalities in Serbia are in the process of the LSDS implementation, and some $15 \%$ are in the drafting phase.

- In Bosnia - Herzegovina and Montenegro, SD strategic planning is mainly donor-driven now. The UNDP Integrated Local Development Programme (UNDP ILDP) was highly involved in municipal strategic planning, and in a few municipalities in Bosnia - Herzegovina. These efforts were supported by the World Bank, OSCE, the Swiss Agency for Development and Cooperation, Municipal Support Programme, and USAID.

- An important local strategic initiative in all the three countries was the development of Local Environmental Action Programmes (also referred to as Local Environmental Action Plans / LEAP). The Regional Centre for the Environment for SEE played (and still plays) a significant role in setting up the methodology and thereby supporting municipalities in LEAP formulation. For example, as of 2006, 20\% of the 148 municipalities in Bosnia - Herzegovina (64 municipalities in the Republic of Srpska, and 84 municipalities in the Federation of Bosnia Herzegovina) have already developed and adopted the LEAP document. The same situation was also found in Serbia and Montenegro.

Table 1 shows the map of the current status of strategic planning for local sustainable development in the analysed Drina River Basin municipalities.

\section{Analysis of LSDS Planning Processes and Achievements}

The analysis of local sustainable development planning and the strategic documents in the Drina River Basin indicates that almost all municipalities have some kind of sustainable development strategy document (sustainable development strategy or at least LEAP), or other sectoral strategy or action plan that can provide a starting point to be included into the local sustainable development strategy. Local self-government employees and experts conducted the majority of these planning processes as a team exercise in a participatory 
manner, although, in some cases, experts or consulting firms were hired to prepare strategic documents.

The analysis of local planning processes shows significant differences among municipalities. By using mainly capacity-building training and donor projects, some municipalities have increased the quality of human resources in the areas of strategic planning, project preparation, and management. There is a strong correlation between the size of the municipality and its level of preparedness for strategic planning in all the three countries.

Although the participatory planning methodology is widely used in all the three countries, many different methodologies are still employed for development planning, from those exclusively based on the engagement of consultants to those exclusively based on civic participation. There is (still) no unified methodology for local sustainable planning, although some efforts have been made in Serbia, and Bosnia - Herzegovina to develop such a methodology. Moreover, the SCTM's Local Sustainable Development Programme has been developed as a participatory planning methodology for LSD strategic planning, followed by methodological textbooks. The best results in the unification of methodological approaches for local development planning have recently been obtained in Bosnia - Herzegovina (MiPRO methodology).

In some cases, the adopted strategic plans were not revised during and after the planning period. As a rule, the full planning cycle (including planning, implementation, monitoring, evaluation, and revision) was rarely followed.

In most cases, strategic plans lack action plans, so the strategy never becomes implementable. In some cases, strategies contain an expansive vision without any realistic connection to the actual resources local self-governments will have in a certain period of time. In cases where we can observe methodologically correctly prepared action plans, the most noticeable oversight is at the budget-planning level. Budgets are mainly addressed to the central government and donors without reference to reasonably available local government budgets.

There is no coordination among papers adopted in the municipality, so it is not uncommon to find conflicting priorities. For example, according to its strategic documents, a municipality's stated priorities can be organic food, heavy industry, and tourism at the same location and time.

Implementation (including monitoring and control) are the weakest points of strategic planning. In most cases, local development does not follow any strategy or plan, but it is the result of current political issues, or part of the donors' bigger projects. Budgets are prepared without substantial cross-sectoral consultation, so 
usually none of the projects from the action plan are included in the funding for the year to come. In most cases, monitoring and control do not exist.

In general, local sustainable development planning in the Drina River Basin can be characterised as an ascending process with the following shortcomings and deficiencies:

- The current methodological framework for planning is inadequate in many aspects, and there is insufficient awareness and understanding of why strategies are necessary and beneficial; only approximately one third of strategies are fully integrated plans as opposed to single-issue plans.

- In particular, current plans do not take into account monitoring, evaluation, and reporting.

- There is a low rate of citizen and business participation in the planning process.

- Planning does not necessarily lead to implementation. Since the mechanism for action planning is missing, there are inadequate links to municipal budgeting, and insufficient capacity of human resources.

- A consistent framework for municipal planning needs to be developed, which reflects the full "programming cycle" (planning, implementation, monitoring, and evaluation) that fits into the re-design of plans.

- There is a lack of planning coordination between central and local government in planning on both sides.

- Given that donors are key drivers of municipal planning, there needs to be more effective donor coordination.

Factors and conditions allow the development of organisational capacities to address $L S D$

The analysis of strategic planning processes in the Drina River Basin indicated a high level of participation in the development of strategic papers. Out of 81 documents analysed, only 8 strategies were exclusively developed by external experts. Moreover, those were mainly spatial plans. However, public participation is important only if it is substantial. This includes a real sharing of power and responsibilities, including the decision-making process. This also means that participation continues after the strategy or plan has officially been adopted through the implementation process and, more particularly, the monitoring process. Although they support participatory planning, the municipalities in the region are not ready to share the power and responsibilities with the civil sector yet, and it is an issue that still needs to be addressed.

When analysing public participation in the Drina River Basin, it is obvious that some educational and social institutions, as well as non-governmental organisations, have demonstrated a higher commitment to participate in strategic planning than others. The representatives of the education and social safety sectors 
were among those with the most willingness to work in strategic planning bodies and committees. In turn, municipalities appreciated their participation and gladly included them into their processes. However, the substance of their participation varied: when mayors were asked about the contribution of schools or social services to overall sustainable development efforts in the municipality, their answers were generalised and unclear. Moreover, civilian representatives did not recognise their role in the process either, particularly in the areas of implementation and monitoring. The impression is that civil society is well appreciated as a tool for raising awareness in the early stages of strategy development, but their role in the overall process is not well recognized, and is sometimes neglected. Even so, it is still important to differentiate between the actions of stronger municipalities (i.e., larger and more developed ones where public participation processes are more advanced) and of smaller and underdeveloped ones.

The presence and participation of the business sector was significantly low. The methodologies employed did not succeed in attracting enterprises to participate in strategic planning processes in this case. However, businesses, in general, were not interested in making a contribution: only few companies with corporate social responsibility policies were recorded in the area.

The strategic planning processes for local sustainable development in the region were not well integrated with the national strategic planning system, especially NSDSs, where applicable.

No substantial multilevel government initiative in local sustainability has been recorded in the Drina River Basin. The above-mentioned Drina River Committee has been seen as a seed of cross-border cooperation, and as a mechanism for the promotion of different initiatives as well as for the introduction of sustainable practices. Unfortunately, the political heritage of recent conflicts, differences in the pace of decentralisation, and the lack of internal capacity still adversely influence the establishment of efficient schemes of multilevel governance in the region.

\section{$7 \quad$ Conclusion}

The municipalities of the region have made significant progress in adopting a strategic approach to local development since 2000. The majority of the municipalities analysed have already developed one or more strategic documents, and initiated their implementation. No significant differences were observed between the processes in Serbia, Montenegro, and the Republic of Srpska. However, the municipalities in the Federation of Bosnia - Herzegovina still lack the political and institutional resources to improve local strategic planning: the 
responsibilities for local strategic planning still need to be further clarified between cantons and municipalities.

The employed participatory planning methodology has established radically new participatory decision-making mechanisms in the municipalities involved. The establishment of strategic planning mechanisms has met the need for participatory, non-discriminatory, and transparent processes.

On the other hand, local strategic planning is fragmented and still donor-driven. The proliferation of strategic planning exercises may be observed in larger municipalities, foremost in Serbia, but the co-ordination between central, regional and local government levels (as well as the co-ordination between donors) remains low in all the three countries.

There is sometimes a poor correlation between strategic goals, priorities and activities drafted in different documents. Rather, strategic planning teams within municipalities are introduced as ad hoc groups, tailored for the specific strategic planning process and without any influence on the implementation modes and processes that lead to serious problems in the implementation phase. However, in any event, smaller municipalities have no critical mass of competent people to accomplish both processes (i.e., developing a strategy and implementing it).

The municipalities in the region greatly appreciate a strategic approach to local development and attest to their willingness to participate in such processes. The recognition of participatory planning and the necessity of community involvement are evident among mayors and administrative staff. Larger municipalities already have developed structures and instruments for participatory planning and good cooperation with the civil sector.

On the other hand, municipalities still lack the critical mass of knowledge and expertise for efficient and effective strategic planning exercises. More training is needed, especially and not only for the employees in the municipalities, but also for all stakeholders.

Sustainable development is not widely recognised as a concept throughout the communities in the region. When talking about sustainability, the majority of persons interviewed referred to environmental protection, but not to other dimensions of sustainability. This is particularly evident through the missing link between economic growth and sustainable development.

The culture of participation in the strategic planning and decision-making processes in the region remains insufficient despite broad and proven adoption of participatory planning methodology throughout the region. 
Initially, donor organisational support lacked coordination. This was noticed by donors and local and central authorities, and consequently resulted in better coordination of programmes and activities. Thus, the duplication of programmes and activities was avoided, and an even distribution of support throughout the region was achieved. The practice of "singling out" and achieving strategic aims within municipalities has not sufficiently insisted on integrative strategic approaches, and, instead, it is based on a partial understanding of sectoral policies. Municipalities are faced with the problems of harmonising the strategic documents produced under the influence of different donor methodologies. The activities planned in different sectoral strategies sometimes proved incompatible, even contradictory.

The skills such as project proposal writing, budgeting, monitoring, reporting, and fundraising remain insufficient in the municipalities we have analysed, particularly in the underdeveloped ones. In addition, although planning teams and stakeholders are engaged in drafting a strategy, in a public discussion, and in communicating the strategy within the community, they as a rule do not participate in the implementation phase.

In spite of the obvious efforts made, the local sustainable development activities analysed so far indicate that the mutual coordination of authorities and actors (municipalities, central governments, associations of local governments, and international development agencies) is lacking. This often leads to different planning approaches and methodologies, and to duplication of activity implementation at the local level. On the other hand, municipalities are not encouraged to mutually communicate or co-operate on the basis of territoriality or according to their individual interests.

The basic challenge and a possible threat to further work in the municipalities that have finalized strategic planning processes is the gap between goals and expectations and available financial resources. Currently, there are no adequate central government mechanisms for financing the priorities developed through local sustainable development planning processes in any of the three countries studied. Finally, local sustainable development strategies in the Western Balkans Region are not viable without a supportive policy and a fiscal framework at the sub-national and national levels. Moreover, the 'higher' levels of government are both unwilling and incapable of implementing Agenda 21 without intensive engagement at the local level. 


\section{LEX LOCALIS - JOURNAL OF LOCAL SELF GOVERNMENT S. Milutinovic \& A. Jolovic: Building Capacity for Sustainability: Strategic Planning Processes for Local Sustainable Development Practices in Western Balkan}

\section{References}

Brugmann, J. (1996) Planning for sustainability at local government level, Environment Impact Assessment Review, 16(4-6), pp. 363 - 379.

Bulkeley, H. \& Betsill, M. (2005) Rethinking sustainable cities: Multilevel governance and the 'urban' politics of climate change, Environmental Politics, 14(1), pp. 42 - 63, doi: 10.1080/0964401042000310178.

Fagan, A. (2008) Global-Local Linkage in the Western Balkans: The politics of environmental capacity building in Bosnia - Herzegovina, Political Studies, 56(3), pp. 629 - 652, doi: 10.1111/j.1467-9248.2007.00711.x.

Golusin, M. \& Munitlak - Ivanovic, O. (2009) Definition, characteristic and state of the indicators of sustainable development in South-eastern Europe, Agriculture Ecosystems \& Environment, 130(1-2), pp. 67 - 74, doi: 10.1016/j.agee.2008.11.018.

Lafferty, W. (2004) Introduction: form and function in governance for sustainable development, In: Lafferty, W. (ed.) Governance for sustainable development. The challenge of adapting form to function (Cheltenham, UK: Edward Elgar).

Lafferty, W. \& Meadowcraft, J. (eds.) (2000) Implementing sustainable development: Strategies and initiatives in high-consumption societies (Oxford: Oxford University Press).

Milutinovic, S. (2003) Introducing performance measurement to local administration in Serbia: Options and possibilities, in Sevic, Z. (ed.) Gauging Success: Performance Measurement in South Eastern Europe (Budapest: Local Government and Public Service Reform Initiative).

Milutinovic, S. (2007) Sustainable development in Serbia, in: Pati, R. N. \& Schwarz-Herion, O. (eds.) Sustainable Development: Issues and Perspectives (New Delhi: D. K. Printworld (P) Ltd.).

Milutinovic, S. (2009) The role of local government in local sustainable development planning Serbian case study. Proceedings, $5^{\text {th }}$ Dubrovnik. Conference on Sustainable Development of Energy, $W$ ater and Environment Systems, Special Session "Role and responsibility of local authorities in assuring energy supply and energy security for industry and population", Sept 29 / Oct 3 2009, Dubrovnik, Croatia.

Milutinovic, S. \& Radojevic, D. (2009) Sustainable development strategy of the Republic of Serbia", Proceedings, $5^{\text {th }}$ Dubrovnik Conference on Sustainable Development of Energy, Water and Environment Systems, Special Session "National Strategies for Sustainable Development", Sept 29 / Oct 3 2009, Dubrovnik, Croatia.

Milutinovic, S., Kaludjerovic, L. J., Popovic, A. \& Milenkovic, M. (2005) Local sustainable development strategy in Serbia. Proceedings, Symposium with International Participation: Environment for Europe, Belgrade, May 2005.

Moser, P. (2001) Glorification, Disillusionment or the Way into the Future? The significance of Local Agenda 21 processes for the needs of local sustainability, Local Environment, 6(4), pp. 453 - 467, doi: 10.1080/1354983012009173 4.

Munitlak - Ivanovic, O., Golusin, M., Dodic, S. \& Dodic, J. (2009) Perspectives of sustainable development in countries of South-eastern Europe. Renewable and Sustainable Energy Reviews, 13(8), pp. 2079-2087, doi:10.1016/j.rser.2009.03.004.

OECD (1995) Developing Environmental Capacity: A Framework, for Donor Involvement (Paris: OECD).

Rees, W. (1988) Economics, Ecology and the Role of Environmental Assessment in Achieving Sustainable Development (Ottawa: Canadian Environmental Research Council).

VanDeveer, S. \& Sagar, A. (2005) Capacity building for the environment: North and South, in: Corell, E., Kallhauge, A. C. \& Sjostedt, G. Furthering Consensus: Meeting the Challenges of Sustainable Development beyond 2002 (London: Green Leaf). 
Volkery, A., Swanson, D., Jakob, K., Bregha, F. \& Pinter, L. (2006) Coordination, challenges, and innovations in 19 National sustainable development strategies, World Development, 34(12), pp. 2047-2063, doi: 10.1016/j.worlddev.2006.03.003.

\section{Apendix}

Table 1: Strategic documents and/or processes in selected municipalities in Drina River Basin

$\begin{array}{ll}\text { Municipality } & \text { Strategic documents and/or processes } \\ \text { Šabac } & \text { LED Strategy (by themselves, 2006) } \\ & \text { Social Policy Strategy (DFID, 2009) } \\ & \text { Action plan for Roma (by themselves, 2005) } \\ & \text { Mega project of } 11 \text { municipalities on attracting investment } \\ & \text { zones } \\ \text { Mali Zvornik } & \text { LSDS (IEP, 2006) } \\ & \text { LEAP (REC, 2007) } \\ & \text { AP for Local Development (IEP, 2007) } \\ & \text { Social Protection Strategy (by themselves, 2007) } \\ & \text { LED Strategy (2008) } \\ & \text { Social Protection Strategy (DFID) } \\ & \text { LEAP } \\ \text { Vladimirci } & \text { LED Strategy (USAID, 2006) } \\ & \text { LSDS (by themselves, 2007) } \\ \text { Osecina } & \text { LEAP } \\ & \text { LAP for Children (UNICEF, 2007) } \\ & \text { Regional Waste Management Plan (by themselves, 2007) } \\ & \text { Social Protection Strategy (DFID) } \\ & \text { Assessment of Elderly People Needs } \\ & \text { LSDS (EXCHANGE II, under the development) } \\ & \text { LEAP (EAR, 2005) } \\ \text { Uzice } & \text { Urban development strategy (IAUS, 2005) } \\ & \text { LAP for Children (UNICEF, 2006) } \\ & \text { Action plan for Roma (local NGO, 2006) } \\ & \text { Regional Waste Management Plan (by themselves, 2007) } \\ & \text { Social Protection Strategy (DFID) } \\ & \text { Assessment of local safety and Safer City Strategy } \\ & \text { GIS and TIS } \\ & \text { Housing Strategy (UN Habitat, 2007) } \\ & \text { LED Strategy (MEGA- USAID) } \\ & \text { Vision of Valjevo city (Logo East 2) } \\ & \text { LEAP (REC, 2007) } \\ & \text { LAP for Children (UNICEF, 2006) } \\ & \text { LSDS (SDC MSP, 2008) } \\ & \text { Social Policy Strategy (by themselves, 2005) } \\ & \text { LED Strategy (USAID-IRD, 2005) } \\ & \text { Spatial Plan of Uzice } \\ & \text { Plan of Changes of Uzice } \\ \text { Valjevo } & \end{array}$


Cajetina

Priboj

Sjenica

Berane

Kolasin

Andrijevica

Mojkovac

\section{Žabljak} Tuzla

Ilijaš

Trnovo

Ustikolina
LEAP (EAR and Ministry of Environment, 2007)

LED Strategy (USAID-IRD)

Action Plan of Changes (SDC MSP)

AP for Refugees and Temporarily Displaced Persons

Tourism Development Master Plan (Zlatibor, Zlatar)

Municipal development plan (2008)

Energy efficiency plan

Spatial plan

Master plan of Ribnica

Master Plan of Zlatibor

LSDS (UNDP PRO, 2007)

LEAP (REC, 2007)

LAP for children (UNICEF, 2007)

LED Strategy (regional, UNDP PRO, 2008)

Social Protection Strategy (DFID)

LSDS (UNDP PRO, 2007)

LSDS (Rev., EXCHANGE II)

Social Policy Strategy (DFID)

LAP for Children (2005)

Socioeconomic assessment of the municipality (UNDP)

Assessment of local self-government functioning

LED Strategy (by themselves, 2008)

Action plan for youth (NGO and municipality, 2007)

LAP for Children (UNICEF, 2007)

AP against corruption (Ministry of internal affairs and public administration, Association of municipalities of Montenegro, 2009)

Spatial sustainable development plan (in preparation; Ministry of Environment and Spatial Planning)

Spatial plan of Bjelasica and Komovi (in preparation; Ministry of Environment and Spatial Planning)

Solid waste strategy (in preparation; Ministry of Environmet and Spatial Planning)

AP against corruption (Ministry of internal affairs and public administration, Association of Municipalities of Montenegro, 2009)

Solid waste strategy (in preparation; Ministry of Environmet and Spatial Planning)

Spatial plan (by themselves, in preparation)

Local development strategy (USAID, 2006)

Municipal Development Strategy 2003 - 2013 (2003, Institute for Economy

Tuzla);

Integrated Local Development Strategy 2009-2015 (in preparation, UNDP)

Guidelines for rural development management (2009)

LEAP (2006)

Municipal Development Strategy 2007-2011 (2007, SERDA)

Ethno/Eco Tourism Study (SERDA)

LEAP 2006 (REC) 
Goražde

Bijeljina

Bratunac

Ustiprača

Rudo

Foča

Figure 1:
Municipal Development Strategy Based on Human Rights 2008-2014 (UNDP, 2008)

LEAP (REC, in preparation)

Youth Strategy 2009-2014 (in preparation)

Action plan of inclusion in child safety system for the period to 2010 (UNICEF, Dubai Cares, in preparation)

Strategy of the partnership with citizens (OSCE, 2008)

Municipal Development Strategy to 2015 (Institute for social and economic studies Bijeljina)

LEAP (by themselves, in preparation)

Municipal Development Strategy (OSCE, 2008)

Action plan for wastewater management (by themselves, 2008)

LEAP (by themselves, 2008)

Municipal Development Strategy (2008, Institute of Economic Faculty of East Sarajevo and World Bank, 2008)

LEAP (REC, 2007)

Municipal Development Strategy and Action Plan (OSCE, 2007)

Action Plan for Municipal Infrastructure Improvement (GAP)

LEAP (REC, 2007)

Municipal Development Strategy (UNDP)

LEAP (GAP)

Action plan of inclusion in child safety system for the period to 2010 godine (UNICEF, Dubai Cares, in preparation)

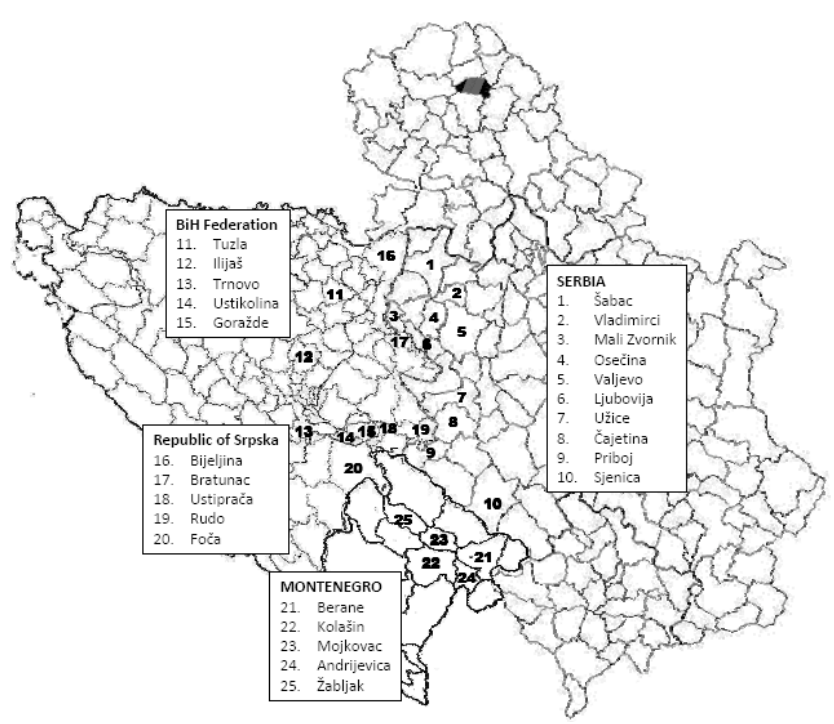


LEX LOCALIS - JOURNAL OF LOCAL SELF GOVERNMENT
S. Milutinovic \& A. Jolovic: Building Capacity for Sustainability: Strategic Planning
Processes for Local Sustainable Development Practices in Western Balkean

\section{Acnowledgements}

This paper is based on fieldwork conducted in 2009 for the project "Education for the sustainable development in the Western Balkans" led by The Regional Environmental Centre for Central and Eastern Europe (REC) and financed by the Ministry for Foreign Affairs of Finland. The authors acknowledge and express appreciation to Tanja Rankovic, Srdjan Susic and Andriela Vitic - Cetkovic for their helpful contribution. The authors also recognize helpful comments by anonymous reviewers. 